\title{
PENGEMBANGAN BAHAN AJAR KITAB ALALA BERBASIS CTL DALAM MENINGKATKAN MOTIVASI BELAJAR
}

\author{
Fathoni \\ Institut Agama Islam Bani Fattah Jombang, Indonesia \\ fathoni@iaibafa.ac.id
}

\begin{abstract}
The pinnacle of a knowledge is charity because charity is an implementation of that knowledge. Utilization of knowledge in everyday life is the fruit of that knowledge, culture rather than doing something based on science, it can be a provision for us to face God. Therefore education really needs more attention and education will not be successful without the support of several factors that can affect student success, most importantly teaching materials.

The book of "Alala" as a teaching material is a classic book from the thoughts of seekers of Muslim science who want to learn to learn. From that desire, ways of studying knowledge are formed in the form of nadham which contains aphorisms and messages for knowledge seekers contained in the book of "Alala" as the moral basis for knowledge seekers.
\end{abstract}

Keyword: book of "Alala", CTL, Motivation to learn

\section{Pendahuluan}

Pendidikan haruslah dirancang menjadi pendidikan yang berAkhlaq, karena manusia mempunyai tiga potensi, yaitu potensi fisik, potensi akal, dan potensi hati. Tetapi potensi hati yaitu Akhlaq mengendalikan kedua potensi lainya. Jika Akhlaqnya bagus, maka potensi fisik, dan potensi akal digunakan untuk tujuan baik. Sebaliknya, jika Akhlaqnya rusak, maka potensi fisik yang kuat dan potensi akal, akan 
digunakan untuk tujuan jahat. Mereka yang melakukan korupsi sampai milyaran rupiah triliunan rupiah, tentulah orang pandai, tetapi karena Akhlaqnya rusak, maka kepandaian itu digunakan untuk memperkaya diri sendiri dan merugikan orang lain.

Oleh karena itu, seharusnya Akhlaq, ditempatkan menjadi bagian penting dalam pendidikan. Dengan menempatkan pendidikan Akhlaq sebagai bagian penting, diharapkan pendidikan mampu melahirkan orang yang pandai, berbadan sehat, dan berAkhlaq mulia, sehingga mereka akan terdorong untuk menggunakan kekuatan fisik dan kepandaian untuk mengupayakan kesejahteraan masyarakat dan negara. Jangan sampai pendidikan mampu menghasilkan orang-orang pandai dengan fisik yang kua, tetapi akahlaqnya rusak. Al-Ghozali mengibaratkan hati sebagai raja, akal sebagai perdana menteri dan fisik sebagai tentara. Rajalah yang mengambil kebijakan, kemana segala kegiatan negara diarahkan. Perdana menteri bertugas mengatur strategi untuk melaksanakan kebijakan raja. Sedangkan tugas tentara adalah melaksanakan kebijakan dan strategi dari atasan.

Demikian pentingnya Akhlaq dalam kehidupan manusia, sehingga nabi muhammad pernah mengatakan "aku diutus ke bumi ini untuk memperbaiki Akblaq umat" oleh karena itu pendidikan Akhlaq, seharusnya menjadi Akhlaqnya pendidikan. Artinya siapapun yang merancang dn melaksanakan pendidikan harus "dijiwai" oleh Akhlaq mulia. Sehingga menghasilkan rancangan pendidikan yang menempatkan pendidikan Akhlaq sebagai bagian penting dan menghasilkan proses pendidikan yang bersuasana Akhlaq mulia. Dalam undang-undang sintem pendidikan nasional no. 20/2003, disebutkan bahwa pendidikan bertujuan untuk mengembangkan potensi peserta didik agar menjadi manusia beriman dan bertaqwa kepada tuhan yang maha Esa, berAkhlaq mulia, sehat, berilmu, cakap, kreatif, mandiri, dan menjadi warga negara yang demokratis serta bertanggung jawab.

Suatu kesalah kaprahan, menjadi orantua dan guru, ketika menyuruh anaknya untuk membuang sampah pada tempatnya, akan tetapi suatu saat, ada orang tua dan guru membuang sampah sembarangan sampai akhirnya, anaknya berteriak, ayah ngawur, membuang sampah sembarangan. Padahal anaknya masih sangat kecil, sekitar kelas 1 SD. Hal tersebut perlu direnungi. Yang mana ketika menjadi orang tua dan guru menyuruh anak atau anak didiknya melarang membuang sampah sembarangan. Kebiasaan itulah yang ditiru oleh anak-anak dan menjadi " senjata makan tuan".

Hal tersebut mengingatkan kita pada pepatah jawa, "kacang ora ninggal lanjarane“ artinya dalam pertumbuhannya, kacang panjang akan mengikuti batang kayu yang merambat. Pepatah itu, mengajarkan kepada 
kita bahwa perilaku anak tidak akan jauh dari perilaku orang tuanya atau orang yang mendidiknya.

Hadits Nabi mengatakan:

$$
\text { قال رسول لله صل لله عليه وسلم طلب العلم فريضة على كل مسلم ومسلمة. }
$$

Rosululloh bersabda: "menuntut ilmu adalah fardbu ain (kewajiban Individu) bagi setiap muslim dan muslimat".

Islam disamping memerintahkan umatnya untuk belajar, menggali ilmu pengetahuan juga memberikan penghargaan yang sangat istimewa bagi orang yang selalu belajar, menuntut ilmu dan mengembangkan dirinya. Banyak sekali nash dalam al-qur'an dan as-sunnab yang mengisyaratkan tentang martabat orang berilmu, kedudukan para ulama, dan keutamaan belajar. Sebagaimana firman Alloh dalam QS alMujadalah: $11{ }^{1}$

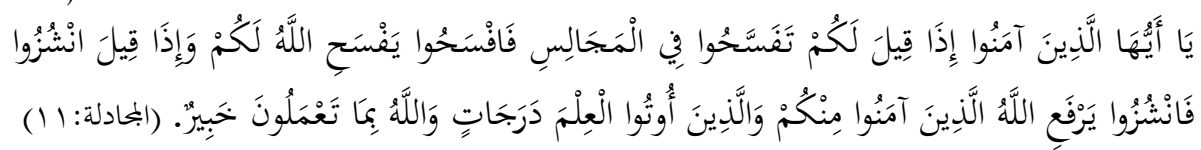

Hai orang-orang beriman apabila kamu dikatakan kepadamu: "Berlapanglapanglah dalam majlis", Maka lapangkanlah niscaya Allah akan memberi kelapangan untukmu. dan apabila dikatakan: "Berdirilab kamu", Maka berdirilah, niscaya Allah akan meninggikan orang-orang yang beriman di antaramu dan orang-orang yang diberi ilmu pengetahuan beberapa derajat. dan Allah Maha mengetabui apa yang kamu kerjakan.

Oleh karena itu pendidikan sangat mebutuhkan perhatian yang lebih dan pendidikan tidak akan berhasil tanpa adanya suatu dukungan beberapa faktor yang dapat mempengaruhi keberhasilan siswa. Kesulitan belajar siswa bukan saja pada pelajaran umum, akan tetapi pelajaran yang sifatnya religius, khususnya pelajaran Akhlaq.

Puncak suatu ilmu adalah amal karena amal merupakan implementasi dari ilmu itu. Pemanfaatan ilmu dalam kehidupan seharihari merupakan buah ilmu itu, pembudayaan daripada melakukan susuatu yang didasarkan atas keilmuwan maka bisa dijadikn bekal kita kelak untuk menghadap Tuhan.

Oleh karena itu pendidikan sangat mebutuhkan perhatian yang lebih dan pendidikan tidak akan berhasil tanpa adanya suatu dukungan beberapa faktor yang dapat mempengaruhi keberhasilan siswa.

Alsan memilih judul ini adalah kerana keunikan kitab Alala dijadikan mata pelajaran Akhlaq yang berbeda dengan yang lainya. Serta

\footnotetext{
${ }^{1}$ Al- Mujadalah, (58) 11, .Departemen Agama RI, Al-Qur'an Dan Terjemahanya, Lajnah Pentashih Al-Qur'an, (Jakarta: Menara Qudus, 2006)
} 
kitab Alala ini merupakan pedoman hidup bagi siswa dalam menta'dhimi guru kelas yang akan datang dalam menta'dhimi guru dan pelajaran Alala dijadikan strategi guru dalam membangun karakter siswa dikelas berikutnya jiwanya para siswa bisa berfikir dewasa, tekun dalam mencari ilmu dan terbiasa dalam melkukan hal yang baik atau bernilai. bisa dikatakan pondasi awal dalam mencari sebuah ilmu yang manfaat dan barokah.

Selain juga sebagai pedoman hidup atau kebudayaan kitab tersebuat memiliki penjelasan yang luas pada kitab Ta'limu Ta'lim baik kitab itu secara bahasa arab maupun yang sudah diterjemahkan memiki tujuan yang sama dan membangun motivasi belajar yang dinginkan, karena kitab Alala ini dalah kitab yang kelasik dari pemikiran para pencari ilmu muslim yang mengingikan barokah ilmu yang di pelajari maka dibentuklah cara-cara dalam menuntut ilmu salah satunya berada di kitab Alala ini.

\section{Pendekatan Kontekstual}

Pendekatan kontekstual atau Contectual Teaching and Lerning (CTL), adalah suatu strategi pembelajaran yang menekankan kepada proses keterlibatan siswa secara penuh untuk dapat menemukan materi yang dipelajari dan menghubungkannya dengan situasi kehidupan nyata sehingga mendorong siswa untuk dapat menerapkannya dalam kehidupan mereka. ${ }^{2}$ Pembelajaran yang dilakukan menurut konteks akan membantusiswa mengaplikasikan kompetensi komunikatif yang dimilikinya dalam kehidupan nyata. ${ }^{3}$

Tiga hal yang harus kita pahami dari konsep tersebut, antara lain: ${ }^{4}$ Pertama, CTL menekankan kepada proses keterlibatan peserta didik untuk menemukan materi, artinya proses belajar diorientasikan pada proses pengalaman secara langsung. Proses belajar dalam konteks CTL tidak mengharapkan agar peserta didik hanya menerima pelajaran, akan tetapi proses mencari dan menemukan sendiri materi pelajaran.

Kedua, CTL mendorong agar peserta didik dapat menemukan hubungan antara materi yang dipelajari dengan situasi kehidupan nyata, artinya peserta didik dituntut untuk dapat menangkap hubungan antara pengalaman belajar di sekolah dengan kehidupan nyata. Hal ini sangat penting, sebab dengan dapat mengkorelasikan materi yang ditemukan

\footnotetext{
2 Depdiknas, Pendekatan Kontekstual, Contextual Teaching and Learning/CTL, (Jakarta: Dirjen Pendidikan Dasar Dan Menengah, 2002), 5.

${ }^{3}$ Ulin Nuha, Nur Sholeh, Pengembangan Kurikulum Bahasa Arab Analisis dan Panduan Kurikulum Bahasa ARAb sesuai KTSP, (Jogjakarta: Diva Prees, 2013), 145.

${ }^{4}$ Wina Sanjaya, Strategi Pembelajaran Berorientasi Standar Proses Pendidikan (Jakarta:

Kencana, 2011), 255-256.
} 
dengan kehidupan nyata, bukan saja bagi peserta didik, materi itu akan bermakna secara fungsional, akan tetapi materi yang dipelajarinya akan tertanam erat dalam memori peserta didik, sehingga tidak akan mudah dilupakan.

Ketiga, CTL mendorong peserta didik untuk dapat menerapkannya dalam kehidupan, artinya CTL bukan hanya mengharapkan peserta didik dapat memahami materi yang dipelajarinya, akan tetapi bagaimana materi pelajaran itu dapat mewarnai perilakunya dalam kehidupan sehari-sehari. Materi pelajaran dalam konteks CTL bukan untuk ditumpuk di otak dan kemudian dilupakan, akan tetapi sebagai bekal mereka dalam mengarungi kehidupan nyata.

Berdasarkan pemaparan di atas, penulis dapat menarik kesimpulan bahwa Pembelajaran CTL dapat mendorong peserta didik menemukan hubungan antara materi yang dipelajari dengan situasi kehidupan nyata. Artinya, peserta didik secara tidak langsung dituntut untuk menangkap hubungan antara pengalaman belajar di sekolah dengan kehidupan nyata di lingkungan masyarakat, sehingga mampu menggali, berdiskusi, berpikir kritis, dan memecahkan masalah nyata yang dihadapinya dengan cara bersama-sama.

Hal ini menunjukkaan bahwa seseorang belajar Akhlaq sayogyanya bahasa yang dipelajari tersebut dapat dipraktikkan dalam kehidupan nyata, yakni mereka dapat menggunakan Akhlaq tersebut untuk bersosialisasi dengan masyarakat.

Dengan begitu dapat ditarik dua hal pokok, yakni mengenai peran guru dan peran siswa dalam pembelajaran. Dalam menggunakan pendekatan ini, siswa harus yakin bahwa apa yang mereka pelajari bermanfaat bagi mereka sedangkan tugas guru harus meyakinkan kepada siswa bahwasanya yang mereka pelajari tersebut itu berguna dan guru harus menjadi fasiltator yang membimbing siswa untuk dapat menemukan sendiri hal-hal yang seharusnya mereka temukan. Pendekatan ini juga menuntut siswa agar siswa memposisikan sebagai diri sendiri yang sedang mencari bekal untuk hidupnya nanti. Dan guru berperan sebagai pengarah dan pembimbing.

Sementaara itu, Kunandar mengemukakan bahwa CTL merupakan konsep belajar yang beranggapan bahwa peserta didik akan belajar lebih baik jika lingkungan diciptakan secara alamiah. ${ }^{5}$

Artinya, belajar akan bermakna jika siswa bekerja dan mengalami sendiri apa yang sedang dipelajari, bukan sekedar mengetahuinya, pembelajaran tidak hanya kegiatan mentransfer pengetahuan dari guru

\footnotetext{
${ }^{5}$ Kunandar, Guru Profesional (Jakarta: PT. Raja Grafindo Persada, 2007), 271.
} 
untuk siswa, akan tetapi siswa mampu memaknai dari apa yang dipelajari. Dan pendekatan ini menganut pada teori Kontruktivisme.

\section{Teori kontruktivisme}

Pendekatan Kontruktivisme pada dasarnya menekankan pentingnya siswa membangun sendiri pengetahuan mereka lewat keterlibatan aktif proses belajar mengajar. Proses belajar mengajar lebih diwarnai student contered daripada teacher contered. sebagian besar waktu proses belajar mengajar berlangsung dengan berbasis pada aktivitas siswa. ${ }^{6}$

Teori Kontruktivisme beranggapan bahwasanya belajar lebih menekankan pada proses dari pada hasil. Hasil belajar sebagai tujuan dinilai penting, tetapi proses yang melibatkan cara dan strategi dalam belajar juga dinilai penting. Dalam proses belajar, hasil belajar, cara belajar, dan strategi belajar akan mempengaruhi perkembangan tata pikir dan skema berfikir seseorang. ${ }^{7}$

Dari anggapan diatas bahwasanya pengetahuan adalah bentukan secara mendalam dan mengenal. Kontruktivisme menurut Piaget, proses berfikir melibatkan dua jenis proses yang saling berhubungan, yaitu mengorganisasikan dan mengadaptasi atau merubah informasi atau pengetahuan. $^{8}$

Kontruktivisme menurut Vygotsky ${ }^{9}$, berpendapat bahwa pengetahuan dibangun secara sosial, bahwa pengertian peserta yang terlibat didalam suatu interaksi sosial akan memberikan kontribusi dan membangun bersama makna suatu pengetahuan. ${ }^{10}$

Hal ini menjadi fungsional pendekatan terhadap pembelajaran matematika karna belajar matematika sangatlah butuh asosiasi, media belajar, pelatihan pelatihan, motivasi dan belajar yang mengasyikkan.

Pendekatan berbasis Kontruktivisme ini merupakan landasan berfikir pendekatan kontekstual, yaitu bahwa pendekatan dibangun oleh manusia sedikit demi sedikit hasilnya diperluas melalui konteks yang terbatas dan dengan tidak tiba-tiba.

\section{Asas Pembelajaran CTL}

\footnotetext{
6 Trianto, Model-Model Pembelajaran Inovatif Berorientasi Kontruktivistik, (Jakarta: Prestasi Pustaka, 2011), cet-5, 106.

${ }^{7}$ Udin, Winata Putra Dkk. Teori Belajar Dan Pembelajaran, (Jakarta: Universitas Terbuka, 2007), cet-2, 6.

${ }^{8}$ Udin, Winata Putra Dkk. Teori Belajar Dan Pembelajaran, 6.8

${ }^{9}$ Vigotsky, seorang psikolog dari rusia, yang meninggal pada usia yang masih muda, yaitu 38 tahun. Selama usianya yang relative muda, dia telah menghasilkan lebih dari 100 buku dan artikel.

${ }^{10}$ Ibid., 6.9
} 
Pendekatan CTL memiliki tujuh komponen utama, yaitu konstruktivisme (Contructivism), menemukan (Inquiry) bertanya (Questioning), masyarakar-belajar (Learning Community), permodelan (Modeling), refleksi (Reflection) dan penilaian yang sebenarnya (Authentic Assesment). Sebuah kelas dikatakan menggunakan pendekatan CTL jika menerapkan ketujuh komponen tersebut dalam pembelajarannya. ${ }^{11}$

Konstruktivisme (Constructivism)

Konstruktivisme lahir dari gagasan Jean Piaget dan Vigotsky. Hakikat dari teori konstruktivisme adalah ide bahwa siswa harus menjadikan hal-hal yang dielajari itu menjadi miliknya sendiri.

Menemukan (Inquiry)

Proses menemukan merupakan kegiatan inti dari pembelajaran kontekstual. Pengeatahuan dan keteramilan yang diperoleh siswa diharapkan bukan hasil proses mengingat materi yang disajikan guru, melainkan hasil dari menemukan sendiri fakta-fakata yang dipelajari. Guru harus selalu merancang kegiatan inkuiri ini dalam setiap pembelajaran yang dikelolanya. Kegiatan inkuiri yang harus dirancang guru meliputi: observasi (observation), bertanya (questioning), mengajukan dugaan (hiphotesis), pengumpulan data (data gathering), penyimpulan (conclussion). Kata kunci strategi inkuiri adalah 'siswa menemukan sendiri'. Untuk menumbuhkan semangat siswa untuk melakukan kegiatan menemukan sediri tersebut, maka guru harus senantiasa mengembangkan sifat ingin tahu siswa dengan bertanya.

Bertanya (Questioning)

Pengetahuan yang dimiliki seseorang selalu bermula dari bertanya, karena bertanya merupakan strategi pembelajaran yang produktif.

Kegiatan bertanya berguna: 1. Menggali informasi, 2. Mengecek pemahaman siswa, 3. Membangkitkan respon pada siswa, 4. Mengetahui sejauh mana keingintahuan siswa, 5. Mengetahui hal-hal yang diketahui siswa, 6. Mengfokuskan siswa dari apa yang dikehendaki guru, 7. Untuk membangkitkan banyak lagi pertanyaan dari siswa, 8. Untuk menyegarkan kembali pengetahuan siswa.

Masyarakar Belajar (Learning Community)

Konsep ini menyarankan agar hasil pembelajaran diperoleh dari kerja sama dengan orang lain.

Permodelan (Modeling)

11 Ulin Nuha, Nur Sholeh, Pengembangan Kurikulum Bahasa Arab Analisis dan Panduan Kurikulum Bahasa ARAb sesuai KTSP, (Jogjakarta: Diva Prees, 2013), 142-143. 
Ketika seorang guru atau salah seorang siswa membacakan puisi di muka kelas, ia menjadi model bagi para siswa. Model dapat didatangkan dari kelas lain atau dari luar sekolah. Guru dapat menghadirkan juara baca puisi atau penyair untuk membacakan puisi di muka kelas. Model dapat juga berupa rekaman audio atau audio visual.

\section{Refleksi (Reflection)}

Refleksi adalah sebuah proses perenungan yang dilakukan oleh mengenai pengetahuan dan keterampilan yang baru saja dipelajarinya dan yang sudah menjadi miliknya.

Penilaian Otentik (Authentic Assessment)

Penilaian merupakan proses pengumpulan berbagai data yang dapat memberikan gambaran tentang perkembangan belajar siswa.

\section{Pembelajaran dengan pendekatan kontekstual}

Pembelajaran itu untuk dinikmati, dengan begitu, tugas guru adalah bagaimana siswa dapat menikmati pembelajaran tersebut. Dan nikmat itu timbul dari rasa diri sendirinya siswa, tugas guru adalah bagaimana pembelajaran bisa menjadikan pembelajaran untuk dinaikmati dan dirasakan dan bisa dilakukan pada kehidupan sehari hari.

\section{Karakteristik Pembelajaran CTL}

Johnson dalam Kunandar mengemukakan bahwa, ada delapan komponen utama dalam sistem pembelajaran kontekstual, yaitu: ${ }^{12}$

1) Melakukan hubungan yang bermakna. Artinya, peserta didik dapat mengatur diri sendiri sebagai orang yang belajar secara aktif dalam mengembangkan minatnya secara individual, orang yang dapat bekerja sendiri atau bekerja dalam kelompok dan orang yang dapat belajar sambil berbuat.

2) Melakukan kegiatan-kegiatan yang signifikan. Artinya, peserta didik membuat hubungan-hubungan antara sekolah dan berbagai konteks yang ada dalam kehidupan nyata sebagai pelaku bisnis dan sebagai anggota masyarakat.

3) Belajar yang diatur sendiri.

4) Bekerja sama. Artinya, peserta didik dapat bekerja sama, guru membantu peserta didik bekerja secara efektif dalam kelompok, membantu mereka memahami bagaimana mereka saling memengaruhi dan saling berkomunikasi.

5) Berpikir Kritis dan Kreatif. Artinya, peserta didik dapat menggunakan tingkat berpikir yang lebih tinggi secara kritis dan

${ }^{12}$ Kunandar. Guru Profesional. (Jakarta: PT Raja Grafindo Persada, 2011), 302-303. 
kreatif, dapat menganalisis, membuat sintesis, memecahkan masalah, membuat keputusan, dan menggunakan logika serta bukti.

6) Mengasuh atau memelihara pribadi peserta didik. Artinya, peserta didik memelihara pribadinya: mengetahui, memberi perhatian, memiliki harapan-harapan yang tinggi, memotivasi dan memperkuat diri sendiri. peserta didik tidak dapat berhasil tanpa dukungan orang dewasa.

7) Mencapai standar yang tinggi (reaching high standards). Artinya, peserta didik mengenal dan mencapai standar yang tinggi: mengidentifikasi tujuan dan memotivasi peserta didik untuk mencapainya. Guru memperlihatkan kepada peserta didik cara mencapai apa yang disebut "excellence".

8) Menggunakan penilaian autentik (using authentic assessment).

Berdasarkan pemaparan di atas, penulis dapat menarik kesimpulan bahwa karakteristik pembelajaran CTL antara lain: adanya kerja sama antar semua pihak, menekankan pentingnya pemecahan masalah atau problem, bermuara pada keragaman konteks kehidupan peserta didik yang berbeda-beda, saling menunjang, menyenangkan tidak membosankan, belajar dengan bergairah dan siswa aktif dalam proses pembelajaran.

\section{Keunggulan dan Kelemahan CTL}

Suatu pendekatan pembelajaran mempunyai keunggulan dan kekurangan, demikian pula dengan pendekatan pembelajaran CTL. Keunggulan pendekatan pembelajaran CTL, antara lain: ${ }^{13}$

1) Pembelajaran CTL dapat mendorong peserta didik menemukan hubungan antara materi yang dipelajari dengan kehidupan nyata

2) Pembelajaran CTL mampu mendorong peserta didik untuk menerapkan hasil belajarnya dalam kehidupan nyata.

3) Pembelajaran CTL menekankan pada proses keterlibatan peserta didik untuk menemukan materi.

Selain keunggulan pendekatan pembelajaran CTL yang sudah peneliti sampaikan diatas, pendekatan pembelajaran CTL juga mempunyai keterbatasan yang merupakan alternatif yang harus diantisipasi oleh guru sehingga dalam pelaksanaannya dapat mengurangi kelemahan tersebut. Berikut ini beberapa kelemahan dari pendekatan pembelajaran CTL, antara lain:

13 Suyadi. Strategi Pembelajaran Pendidikan Karakter. (Bandung: PT Remaja Rosdakarya, 2013) , 95-96 
1) CTL membutuhkan waktu yang lama bagi peserta didik untuk bisa memahami semua materi.

2) Guru lebih intensif dalam membimbing, karena dalam metode CTL guru tidak lagi berperan sebagai pusat informasi.

3) Upaya menghubungkan antara materi di kelas dengan realitas di dalam kehidupan sehari-hari peserta didik rentan kesalahan. Atas dasar ini, agar menemukan hubungan yang tepat, sering kali peserta didik harus mengalami kegagalan berulang kali.

Berdasarkan pemaparan di atas, penulis dapat menarik kesimpulan bahwa Suatu pendekatan pembelajaran mempunyai keunggulan dan kekurangan, demikian pula dengan pendekatan pembelajaran CTL, keunggulan pendekatan pembelajaran CTL dapat meningkatkan kwalitas belajar peserta didik, sedangkan kelemahan atau keterbatasan merupakan alternatif yang harus diantisipasi oleh guru sehingga dalam pelaksanaannya dapat mengurangi kelemahan tersebut.

\section{Kitab Alala}

Kitab Alala isinya berbentuk 37 bait syair-syair arab beserta arti yang bertuliskan tulisan pego, disusun sangat sederhana, dan isinya sangat dalam, dan kitabnya tidak ada nama pengarangnya.

Kitab Alala terdapat dalam berbagai kitab, dan dikumpulkan oleh serta diterjemahkan oleh Romo KH. Abu Al-Futuh dari Wonokasihan, gurah, kediri. Dikitab tersebut tidak ada nama pengarang karena beliau sangat tawadhu'.

Dalam Kitab Alala bahwasanya kitab tersebut, berisi tentang motivsi belajar, dalam buku bukanlah penjelasan teoritis melainkan pada bentuk struktural pemberian motivasi secara langsung dengan berbagai bentuk, aspek, dan strategi yang ada dalam pembelajaran. Beberapa nadhom Alala juga menjelaskan aspek-aspek motivasi belajar, terutama aspek dorongan untuk mencapai sesuatu, bentuk-bentuk motivasi belajar terdiri dari 2 bentuk yaitu, intrinsik, dan motivasi eksrinsik, namun nadhom Alala lebih memotivasi secara intrinsik. Dan motivasi belajar untuk menyeleksi perbuatan-perbuatan yang harus dijalani guna untuk mencapai tujuan, dan meninggalkan sesuatu atau perbuatan yang tidak bermanfaat untuk mencapai tujuan. kitab Alala ada juga faktor yang mempengaruhi motivasi belajar, Faktor-faktor itu terbagi menjadi dua bagian yaitu, internal dan eksternal.

\section{Teks Kitab Alala}

\begin{tabular}{|c|c|c|}
\hline Bait & Terjemah & Teks \\
\hline 1 & $\begin{array}{ll}\text { Ingatlah..... } & \text { kalian tidak akan } \\
\text { mendapatkan } & \text { ilmu yang bermanfaat }\end{array}$ & 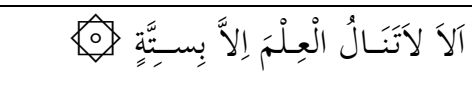 \\
\hline
\end{tabular}




\begin{tabular}{|c|c|c|}
\hline & kecuali dengan $6[\mathrm{enam}]$ syarat, & 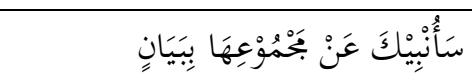 \\
\hline 2 & $\begin{array}{l}\text { yaitu cerdas, semangat, sabar, biaya, } \\
\text { petunjuk ustadz dan lama waktunya. }\end{array}$ & 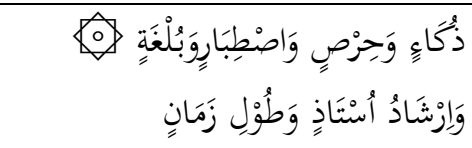 \\
\hline 3 & $\begin{array}{l}\text { Janganlah engkau bertanya tentang } \\
\text { kepribadian orang lain, lihat saja } \\
\text { temannya (pergaulannya), karena } \\
\text { seseorang akan mengikuti apa yang } \\
\text { dilakukan teman-temannya, }\end{array}$ & 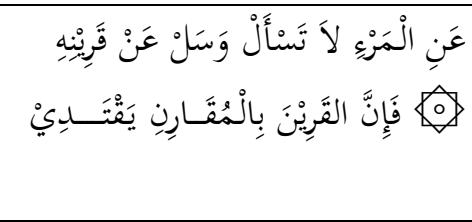 \\
\hline 4 & $\begin{array}{l}\text { bila temannya (pergaulannya) tidak } \\
\text { baik maka jauhilah dia secepatnya, dan } \\
\text { bila temannya (pergaulannya) baik } \\
\text { maka temanilah dia, dengan kamu akan } \\
\text { mendapatkan petunjuk. }\end{array}$ & 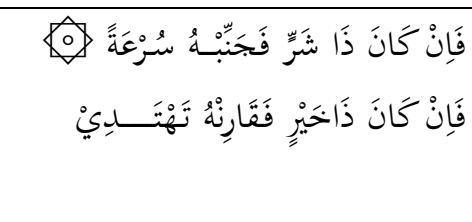 \\
\hline 5 & $\begin{array}{l}\text { Belajarlah, ilmu adalah perhisan indah } \\
\text { bagi pemiliknya, dan keutamaan } \\
\text { baginya serta tanda setiap hal yang } \\
\text { terpuji }\end{array}$ & 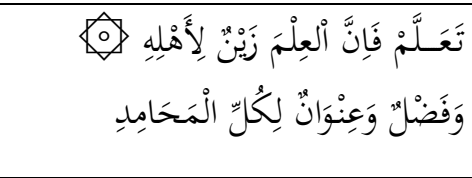 \\
\hline 6 & $\begin{array}{l}\text { Mengajilah setiap hari untuk } \\
\text { menambah ilmu yang kau miliki, lalu } \\
\text { berenanglah dilauatan fa'edah- } \\
\text { fa'edahnya }\end{array}$ & 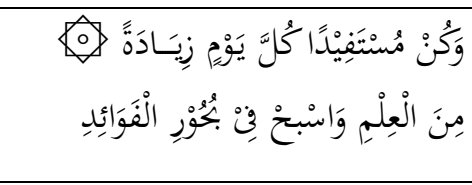 \\
\hline 7 & $\begin{array}{l}\text { Pelajarilah ilmu fiqih karena ilmu fiqih } \\
\text { adalah sebaik-baik penuntun menuju } \\
\text { kebaikan dan ketakwaan, }\end{array}$ & 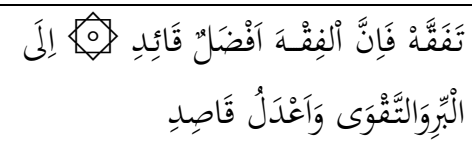 \\
\hline 8 & $\begin{array}{l}\text { Ilmu fiqih adalah lambang yang } \\
\text { menunjukkan jalan hidayah, dan } \\
\text { benteng yang menjaga dari setiap } \\
\text { sesuatu yang memberatkan }\end{array}$ & 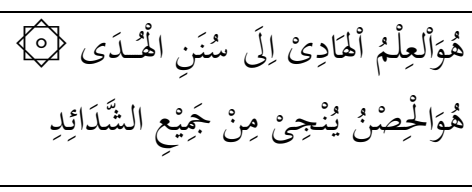 \\
\hline 9 & $\begin{array}{l}\text { Satu ahli fiqih yang wira'i [ menjauhkan } \\
\text { diri dari larangan Allah ta'ala dan } \\
\text { menjalankan perintahnya ] lebih } \\
\text { ditakuti oleh syetan daripada seribu } \\
\text { ahli ibadah [yang tidak ahli fiqih atau } \\
\text { ahli fiqih tapi tidak wira'i] }\end{array}$ & 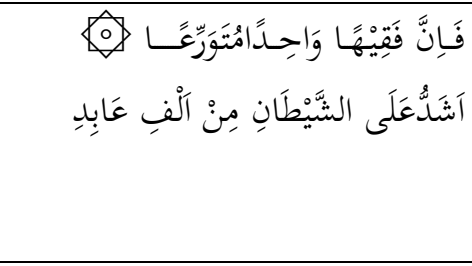 \\
\hline 10 & $\begin{array}{l}\text { Suatu kerusakan besar adalah orang } \\
\text { alim yang tidak mengamalkan ilmunya, } \\
\text { namun kerusakan yang lebih besar } \\
\text { adalah orang bodoh yang beribadah }\end{array}$ & 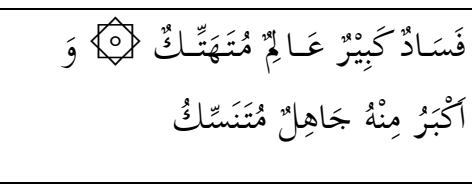 \\
\hline 11 & $\begin{array}{l}\text { Keduanya merupakan fitnah yang } \\
\text { besar didalam alam semesta ini, yaitu } \\
\text { bagi orang yang berpegang teguh pada } \\
\text { agamanya. }\end{array}$ & 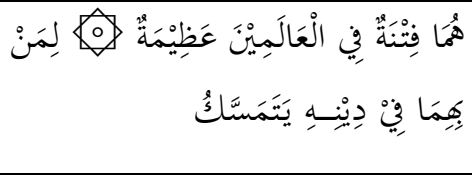 \\
\hline
\end{tabular}




\begin{tabular}{|c|c|c|}
\hline 12 & $\begin{array}{l}\text { Kamu berharap ingin jadi ahli fiqih } \\
\text { yang bisa menerapkan hujjah atas } \\
\text { setiap permasalahannya, dengan tanpa } \\
\text { usaha keras itu namanya gila dan gila } \\
\text { itu bermacam-macam. }\end{array}$ & 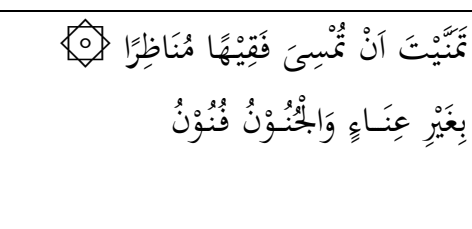 \\
\hline 13 & $\begin{array}{l}\text { Sementara mencari harta tanpa usaha } \\
\text { keras bukanlah tidaklah mungkin, lalu } \\
\text { apalagi ilmu? }\end{array}$ & 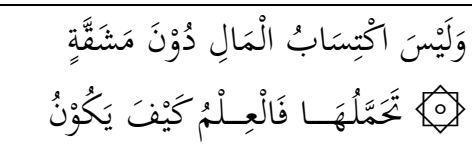 \\
\hline 14 & $\begin{array}{l}\text { Bila sempurna akal seseorang [cerdas] } \\
\text { maka sedikitlah bicaranya, dan yakinlah } \\
\text { akan bodohnya orang yang banyak } \\
\text { bicara. }\end{array}$ & 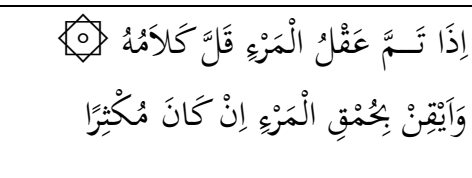 \\
\hline 15 & $\begin{array}{l}\text { Pemuda bisa mati sebab tergelincir } \\
\text { lisannya (salah bicara), tapi tidak mati } \\
\text { karena tergelincir kakinya (jatuh), }\end{array}$ & 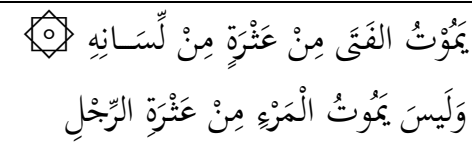 \\
\hline 16 & $\begin{array}{l}\text { sebab tergelincirnya mulut bisa } \\
\text { melenyapkan kepalanya sementara } \\
\text { tergelincirnya kaki sembuh sebentar } \\
\text { kemudian }\end{array}$ & 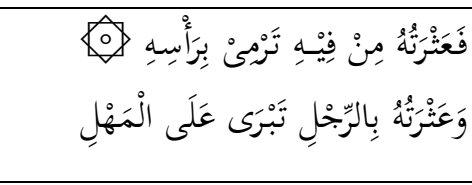 \\
\hline 17 & $\begin{array}{l}\text { Orang yang berilmu akan tetap hidup } \\
\text { setelah matinya walaupun tulang- } \\
\text { tulangnya telah hancur di bawah bumi, }\end{array}$ & 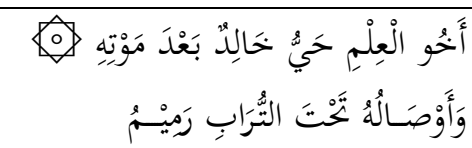 \\
\hline 18 & $\begin{array}{l}\text { sementara orang yang bodoh telah } \\
\text { mati walaupun masih berjalan di atas } \\
\text { bumi, dia menganggap bahwa dirinya } \\
\text { hidup padahal sebenarnya dia telah } \\
\text { tiada. }\end{array}$ & 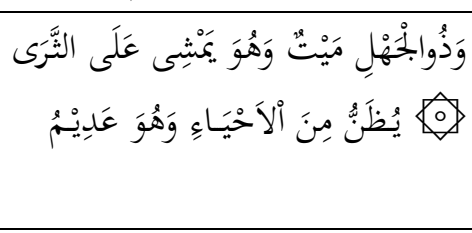 \\
\hline 19 & $\begin{array}{l}\text { Bagi setiap orang untuk [mendapatkan } \\
\text { ] derajat yang luhur [harus dengan] } \\
\text { perjuangan-perjuangan, tapi sedikit } \\
\text { dari mereka yang tabah [dalam } \\
\text { perjuangannya] }\end{array}$ & 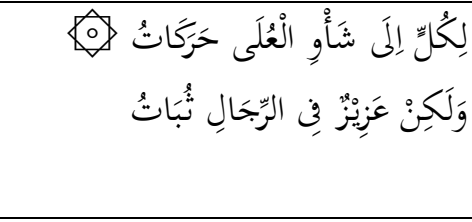 \\
\hline 20 & $\begin{array}{l}\text { Bila kamu bersama orang banyak } \\
\text { (bermasyarakat), maka bergaullah } \\
\text { dengan orang yang terbaik dari } \\
\text { mereka, jangan kamu bergaul orang } \\
\text { yang terburuk diantara mereka, karena } \\
\text { kamu akan buruk bersama mereka. }\end{array}$ & 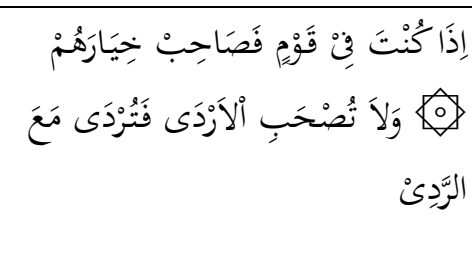 \\
\hline 21 & $\begin{array}{l}\text { Saya lebih utamakan ustadzku dari } \\
\text { pada orang tua kandungku, meskipun } \\
\text { aku mendapatkan keutamaan dan } \\
\text { kemulyaan dari orang tuaku }\end{array}$ & 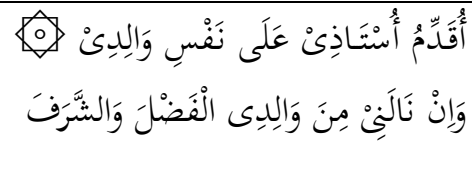 \\
\hline
\end{tabular}




\begin{tabular}{|c|c|c|}
\hline 22 & $\begin{array}{l}\text { Ustadzku adalah pembimbing jiwaku } \\
\text { dan jiwa adalah bagaikan mutiara, } \\
\text { sedangkan orang tuaku adalah } \\
\text { pembimbing badanku dan badan } \\
\text { bagaikan kerangnya [tempat bagi } \\
\text { jiwaku] }\end{array}$ & 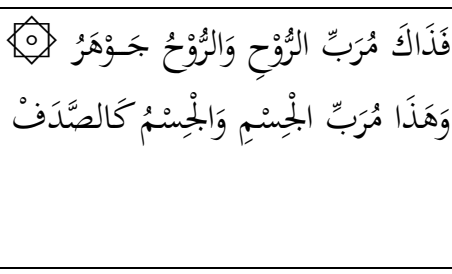 \\
\hline 23 & $\begin{array}{l}\text { Saya melihat lebih haknya sesuatu yang } \\
\text { hak adalah hak dari guru dan bahwa } \\
\text { hak seorang guru adalah wajib di } \\
\text { laksanakan atas setiap orang islam, }\end{array}$ & \\
\hline 24 & $\begin{array}{l}\text { sesungguhnya benar sekali } \\
\text { memberikan hadiah kepada guru untuk } \\
\text { setiap satu huruf yang di ajarkannya } \\
\text { seribu dirham }\end{array}$ & لَقََ \\
\hline 25 & $\begin{array}{l}\text { Saya melihat kamu mempunyai nafsu } \\
\text { yang ingin engkau muliakan, padahal } \\
\text { kamu tidak akan mendapat kemuliaan } \\
\text { kecuali dengan menghinakan nafsumu. }\end{array}$ & \\
\hline 26 & $\begin{array}{l}\text { Bila perbuatan seseorang buruk, maka } \\
\text { akan buruk pula prasangka- } \\
\text { prasangkanya, dan akan dibenarkannya } \\
\text { kebiasaan - kebiasaan dari } \\
\text { kecurigaannya }\end{array}$ & \\
\hline 27 & $\begin{array}{l}\text { Manusia [yang disekitar kita] hanya } \\
\text { salah satu dari tiga [golongan], }\end{array}$ & 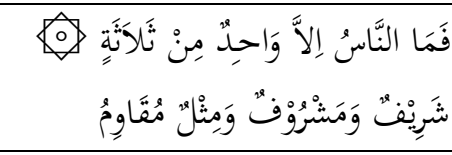 \\
\hline 28 & $\begin{array}{l}\text { yaitu orang yang mulia, rendah dan } \\
\text { sepadan [dengan kita]. orang yang } \\
\text { mulia saya tahu derajatnya dan saya } \\
\text { harus mengikuti sesutau yang haq } \\
\text { darinya, }\end{array}$ & A \\
\hline 29 & $\begin{array}{l}\text { dan orang yang sepadan dengan kita } \\
\text { bila terpeleset atau jatuh maka saya } \\
\text { lebih utama darinya, }\end{array}$ & 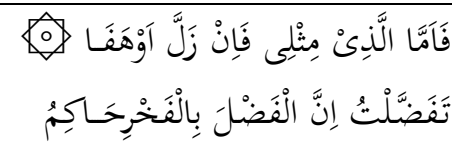 \\
\hline 30 & $\begin{array}{l}\text { sedangkan orang yang rendah maka } \\
\text { saya selalu memberikan kata maaf } \\
\text { kepada mereka untuk menjaga } \\
\text { kehormatanku walaupun banyak orang } \\
\text { yang mencela. }\end{array}$ & 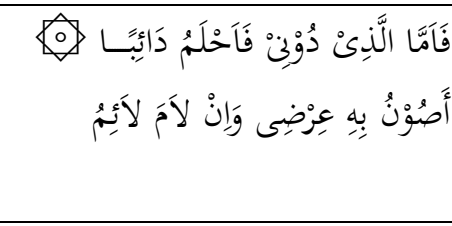 \\
\hline 31 & $\begin{array}{l}\text { Jangan hiraukan orang lain [yang } \\
\text { berbuat jahat kepadamu] jangan } \\
\text { engkau balas perbuatan jahatnya } \\
\text { karena dia akan di balas oleh }\end{array}$ & 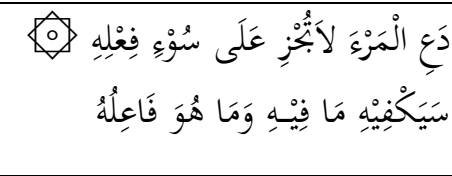 \\
\hline
\end{tabular}




\begin{tabular}{|c|c|c|}
\hline & perbuatannya. & \\
\hline 32 & $\begin{array}{l}\text { Bukankah termasuk kerugian bila } \\
\text { malam-malam berlalu tanpa kita } \\
\text { manfaatkan sedangkan umurmu terus } \\
\text { berkurang? }\end{array}$ & 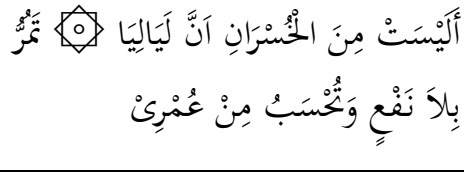 \\
\hline 33 & $\begin{array}{l}\text { Belajarlah....! manusia tidak dilahirkan } \\
\text { dalam keadaan berilmu, dan orang } \\
\text { berilmu tidak seperti orang yang tidak } \\
\text { berilmu }\end{array}$ & 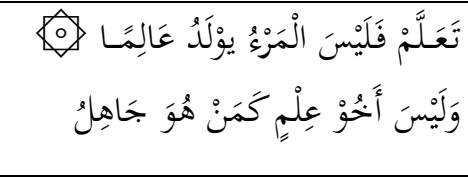 \\
\hline 34 & $\begin{array}{l}\text { Pergilah dari rumahmu untuk mencari } \\
\text { keutamaan (mondok), karenadalam } \\
\text { kepergianmu ada } 5 \text { [lima] faedah, }\end{array}$ & 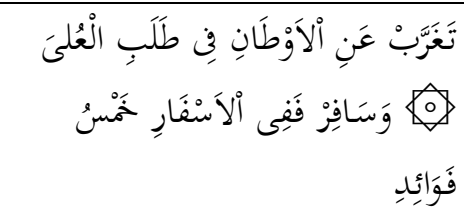 \\
\hline 35 & $\begin{array}{l}\text { yaitu menghilangkan kesusahan } \\
\text {,mencari bekal hidup, ilmu, tatakrama } \\
\text { dan teman sejati. }\end{array}$ & 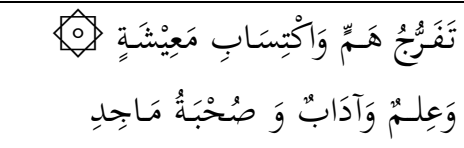 \\
\hline 36 & $\begin{array}{l}\text { meskipun dalam bepergianpun } \\
\text { terdapat hina dan terlunta-lunta, } \\
\text { menembus belantara dan menerjang } \\
\text { kepayahan-kepayahan. }\end{array}$ & 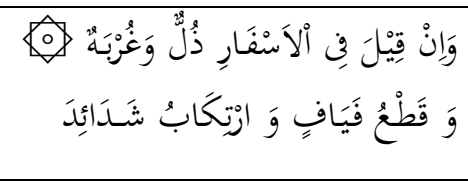 \\
\hline 37 & $\begin{array}{l}\text { Matinya pemuda lebih baik dari pada } \\
\text { hidupnya di daerah kehinaan di antara } \\
\text { orang-orang ahli mengadu domba dan } \\
\text { iri hati. }\end{array}$ & 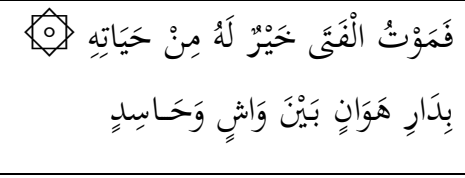 \\
\hline
\end{tabular}

\section{Efektifitas Pengembangan Bahan Ajar Kitab Alala Terhadap Hasil Belajar Siswa}

Pelaksanaan dan tindakan dalam proses pembelajaran pada kegiatan awal seperti biasanya (a) guru mengawali pelajaran dengan salam; (b) mengabsensi siswa yang tidak hadir; (c) melakukan apersepsi artinya mengecek pengetahuan siswa tentang pelajaran yang telah dilakukan dan matapelajaran yang akan disampaikan.

Pada kegiatan inti dimulai dengan (a) guru menginformasikan tujuan pembelajaran; (b) guru membentuk kelompok siswa untuk melakukan diskusi, (c) guru menjelaskan tentang materi dan kegiatan yang akan dilakukan siswa. Observasi selama proses pembelajaran berjalan, baik kegiatan guru maupun kegiatan siswa dilakukan oleh teman sejawat/teman guru lainnya serta peneliti. Guna dari observasi adalah untuk memberikan masukan dari hasil pengamatan selama proses pembelajaran berlangsung. Pengamatan tersebut mulai dari kegiatan awal, kegiatan inti, dan kegiatan akhir, hal ini sebagai pedoman dalam perbaikan pembelajaran pada siklus II. Sedangkan siswa diberikan 
beberapa pertanyaan untuk melihat apakah siswa dapat memecahkan masalah materi pelajaran yang ditugaskan guru kepada mereka.

Pada kegiatan akhir, peneliti untuk melengkapi proses pembelajaran pada PTK, maka diperoleh data tambahan yaitu Lembar Kerja Siswa (LKS), lembar pengamatan, daftar nilai harian. Terakhir tes untuk mengetahui hasil belajar siswa disusun oleh guru/peneliti sesuai dengan kompetensi yang ditetapkan. Untuk menentukan ketuntasan dalam penelitian ini adalah (1) rata-rata nilai tes hasil belajar siswa pada pokok bahasan membaca kritis dengan meninjau letak paragraf sebuah wacana.

Ada beberapa hal yang dianalisis untuk mendukung kelayakan produk yang dikembangkan. Dengan adanya analisis kevalidan produk sudah tidak diragukan lagi bahwa Bahan Ajar Baru tersebut benar-benar terbukti kelayakannya sebagai buku acuan tambahan dalam proses belajar. Sebagaimana dalam pembelajaran Akhlaq dengan materi kitab Alala disini yang terpenting adalah terapan ilmu merujuk kesikap dan perilaku. Dalam rangka untuk dapat melihat keefektifan metode pembelajaran Contextual Teaching \& Learning dengan objek materi kitab Alala dapat digunakan metode control dan eksperimen meliputi:

a. Uji beda (uji T) hasil pretest dan posttest kelas

ketika sebelum menggunakan Bahan Ajar baru atau pretest nilai yang didapatkan siswa dibawah KKM, sedangkan setelah menggunakan buku bahan Ajar baru atau posttest nilai siswa sudah di atas rata-rata KKM yang telah ditentukan sebelumnya. Kemudian dilakukan uji $\mathrm{t}$ untuk mengetahui produk yang dikembangkan signifikan pada hasil belajar siswa, baik pada pretest atau posttest.

b. Perubahan perilaku siswa ketika berhadapan dengan guru dan teman-temanya disekolah

\section{Kesimpulan}

Pembelajaran merupakan kegiatan yang sudah seharusnya untuk dilakukan semaksimal mungkin. Pendidiklah yang hendaknya mengarahkan siswa-siswinya untuk mengikuti proses pembelajaran agar mereka dapat memperoleh tujuan pembelajaran yang telah ditentukan dan menjadikan harapan keberhasilan. Tetapi belum mengedepankan apa saja aspek-aspek yang hendaknya dicapai oleh pendidik.

Hasil belajar adalah perubahan prilaku secara keseluruhan bukan hanya salah satu aspek potensi kemanusiaan saja. Artinya hasil pembelajaran yang dikategorisasi aleh para pakar pendidikan sebagaimana tersebut diatas tidak dilihat secara fragmentaris atau terpisah, melainkan komprehensif. 


\section{Penutup}

Sebagai suatu bahan ajar, kitab Alala ini diharapkan dapat menjadi dasar akhlak bagi para siswa dalam menuntut ilmu, sehingga dapat memiliki ilmu yang barokah. Di samping itu sebagai bentuk khazanah keilmuan dan tradisi keilmuan yang ada di nusantara khususnya di jawa pemakaian kitab Alala sebagai bahan ajar memang sudah menjadi rutinitas utamanya di lingkungan pesantren sehingga memilah metode pembelajaran yang optimal layak untuk dikaji.

\section{Daftar Pustaka}

Agama RI, Departemen. 2006. Al-Qur'an Dan Terjemahanya, Lajnah Pentashih Al-Qur'an, Jakarta: Menara Qudus.

Depdiknas. 2002. Pendekatan Kontekstual, Contextual Teaching and Learning/CTL, Jakarta: Dirjen Pendidikan Dasar Dan Menengah.

Kunandar. 2007. Guru Profesional, Jakarta: PT. Raja Grafindo Persada. . 2011. Guru Profesional, Jakarta: PT Raja Grafindo Persada.

Sanjaya, Wina. 2011. Strategi Pembelajaran Berorientasi Standar Proses Pendidikan, Jakarta: Kencana.

Sholeh, Ulin Nuha, Nur. 2013. Pengembangan Kurikulum Bahasa Arab Analisis dan Panduan Kurikulum Bahasa Arab sesuai KTSP, Jogjakarta: Diva Prees.

Suyadi. 2013. Strategi Pembelajaran Pendidikan Karakter. Bandung: PT Remaja Rosdakarya.

Trianto. 2011. Cet. 5. Model-Model Pembelajaran Inovatif Berorientasi Kontruktivistik, Jakarta: Prestasi Pustaka.

Udin, Winata Putra Dkk. 2007. Cet. 2. Teori Belajar Dan Pembelajaran, Jakarta: Universitas Terbuka. 